\title{
Atlantic Geology Special Issue Processes in felsic magma chambers
}

\author{
FOREWORD
}

The papers in this special issue result from a theme session on "Processes in felsic magma chambers - from crystallization and evolution to emplacement" that was convened at the joint meeting of the Northeast Section of the Geological Society of America and the Atlantic Geoscience Society, March $27^{\text {th }}-29^{\text {th }}$, 2003, at the Westin Hotel, Halifax, Nova Scotia.

It has long been realized that plutons contain a wealth of information important in unravelling the complex processes that operate in magma chambers. However, the depth to which a pluton is exposed may constrain the amount and usefulness of these data, unlike volcanic systems where the information has found its way to the surface! Recently though, petrologists have utilized a barrage of microfabric studies, high precision dating techniques, and petrochemical investigations to examine the timing, ascent and emplacement, magma flow, and crystallization history of granitic/plutonic systems and thus detail magma chamber processes.

The papers presented at this theme session covered many of these aspects of magma chamber dynamics. The session attracted 14 oral and 7 poster presentations, the latter all by students, with 40 authors and co-authors from New England and further afield in the USA, Canadian Maritimes, Ontario, Ireland, and Great Britain. Abstracts for the session are published in the 2003 Abstracts with Programs, NEGSA, volume 35 , number 3 .

The papers presented here are examples of the wide range of presentations given at the NEGSA theme session. David Westerman and colleagues investigate "The case of the Monte Capanne pluton”, Elba, Italy, and suggest that competing processes of fractionation and magma mixing occurred to produce the range of hybrid products observed in this intrusion. Kirsten McLaughlin, Sandra Barr and co-workers detail the age, chemistry, and tectonic setting of the Moosehorn plutonic suite, a diverse assemblage of co-magmatic plutons, which likely originated in an extensional, back-arc basin environment. In a trans-Atlantic collaborative project, Martin Feely and Sadhbh Baxter (Galway, Ireland) along with Drew Coleman and Brent Miller (Chapel Hill, NC) present new U-Pb zircon geochronology for the Galway granite, Ireland, constraining final movement along the Southern Uplands fault, a major orogen-parallel structure of the Irish Caledonides. Sub-volcanic granitoid intrusions in the Late Devonian Mount Pleasant Caldera and the associated mineralisation systems are the topic of Xueming Yang, David Lentz, and Steve McCutcheon's paper. They document petrochemical differences between two granitic suites, an earlier gold-generating suite which is comparable to intrusion-related gold systems elsewhere, and a slightly later, more evolved suite with characteristics of topazbearing granite. The Silurian-Devonian Fogo Island Batholith, Newfoundland, is examined by Ken Currie, who shows that the sill-like bimodal body has a complex history including a late influx of mafic magma that resulted in hybrid intermediate rocks. In the last paper of the set, by David Gibson, Dan Lux and Michael Choate, petrographic evidence from the Mount Waldo granite in Maine indicates that mafic inputs fuelled mixing and convection in this magma chamber comparable to that evident in the older suite of plutons that crop out along the Maine coast.

We would like to thank all the contributors to this special issue and also to the reviewers who did an excellent job. We hope that the papers published here will inspire further discussion and examination of magma chambers that will continue to unravel their complexities.

DAVID GIBSON

DEPARTMENT OF NATURAL SCIENCES

UNIVERSITY OF MAINE AT FARMINGTON, FARMINGTON, MAINE

DAN LUX

DEPARTMENT OF GEOSCIENCES

UNIVERSITY OF MAINE, ORONO, MAINE

SANDRA BARR

DEPARTMENT OF GEOLOGY, ACADIA UNIVERSITY, WOLFVILLE, NOVA SCOTIA 
